\title{
Abbreviations and Shortened Forms of Reference
}

The texts listed here are referred to several times. Page numbers, or in the case of poems canto and stanza numbers, for quotations from these will be given in brackets after quotation.

Walter Scott, The Lay of the Last Minstrel: A Poem (London and Edinburgh: Longman, Hurst, Rees, and Orme and A. Constable and Co., 1805)

-, Marmion; A Tale of Flodden Field (Edinburgh and London: Archibald Constable and Company and William Miller and John Murray, 1808)

, The Lady of the Lake: A Poem in Six Cantos (Edinburgh and London: John Ballantyne and Co. and Longman Hurst, Rees, and Orme, and William Miller, 1810)

, Waverley (1814), ed. by P. D. Garside, Edinburgh Edition of the Waverley Novels 1 (Edinburgh: Edinburgh University Press, 2007)

, Guy Mannering (1815), ed. by P. D. Garside, Edinburgh Edition of the Waverley Novels 2 (Edinburgh: Edinburgh University Press, 1999)

—, The Antiquary (1816), ed. by David Hewitt, Edinburgh Edition of the Waverley Novels 3 (Edinburgh: Edinburgh University Press, 1995) , The Tale of Old Mortality (1816), ed. by Douglas Mack, Edinburgh Edition of the Waverley Novels, 4b (Edinburgh: Edinburgh University Press, 1993)

— The Heart of Mid-Lothian (1818), ed. by David Hewitt and Alison Lumsden, Edinburgh Edition of the Waverley Novels 6 (Edinburgh: Edinburgh University Press, 2004)

—, The Bride of Lammermoor (1819), ed. by J. H. Alexander, Edinburgh Edition of the Waverley Novels 7a (Edinburgh: Edinburgh University Press, 1995)

_ Ivanhoe (1820), ed. by Graham Tulloch, Edinburgh Edition of the Waverley Novels 8 (Edinburgh: Edinburgh University Press, 1998)

- The Pirate, ed. by Mark Weinstein with Alison Lumsden, Edinburgh Edition of the Waverley Novels 12 (Edinburgh: Edinburgh University Press, 2001)

, The Fortunes of Nigel (1822), ed. by Frank Jordan, Edinburgh Edition of the Waverley Novels 13 (Edinburgh: Edinburgh University Press, 2004) 
viii Walter Scott and the Limits of Language

— Peveril of the Peak (1822), ed. by Alison Lumsden, Edinburgh Edition of the Waverley Novels 14 (Edinburgh: Edinburgh University Press, 2007)

— - Redgauntlet (1824), ed. by G. A. M. Wood with David Hewitt, Edinburgh Edition of the Waverley Novels 17 (Edinburgh: Edinburgh University Press, 1997)

_- Chronicles of the Canongate (1827), ed. by Claire Lamont, Edinburgh Edition of the Waverley Novels 20 (Edinburgh: Edinburgh University Press, 2000)

, Count Robert of Paris (1831), ed. by J. H. Alexander, Edinburgh Edition of the Waverley Novels 23a (Edinburgh: Edinburgh University Press, 2006)

— Castle Dangerous (1831), ed. by J. H. Alexander, Edinburgh Edition of the Waverley Novels 23b (Edinburgh: Edinburgh University Press, 2000)

- Reliquiae Trotcosienses Or The Gabions of the Late Jonathan Oldbuck Esq. of Monkbarns, ed. by Gerard Carruthers and Alison Lumsden (Edinburgh: Edinburgh University Press in association with The Abbotsford Library Project Trust, 2004)

The following texts are referred to several times and they will be referenced in the notes using the following abbreviations.

Prose Works The Prose Works of Sir Walter Scott, Bart., 28 vols (Edinburgh: Robert Cadell, 1834-6)

Poetical Works The Poetical Works of Sir Walter Scott, Bart., ed. by J. G. Lockhart, 12 vols (Edinburgh: Robert Cadell, 1833-4)

Letters The Letters of Sir Walter Scott, ed. by H. J. C. Grierson and others, 12 vols (London: Constable, 1932-7)

Life J. G. Lockhart, Memoirs of the Life of Sir Walter Scott,

Journal The Journal of Sir Walter Scott, ed. by W. E. K. Anderson (Oxford: Clarendon Press, 1972)

\section{Permissions}

All manuscripts referred to in this text are in the National Library of Scotland (NLS) and are quoted with the kind permission of the Keepers. All quotations from the Edinburgh Edition of the Waverley Novels $($ EEWN) are with the permission of the Editor-in-Chief. 